14. Чуткий А.І. Невідомий аспект з історії польської громади Києва початку XX ст.: Польський гурток та Варшавське земляцтво у Київському комерційному інституті (1908-1914 pp.). Europa Orientalis. Studia z dziejow Europy Wschodniej I panstw Baltyckich. 2015. № 6. S. 11-34.

DOI https://doi.org/10.30525/978-9934-588-91-4-27

\title{
ДЕНІКІНСЬКИЙ РЕЖИМ НА ПІВДНІ УКРАЇНИ 1918-1920 РР. У ДИСЕРТАЦЙНИХ РОБОТАХ СУЧАСНИХ УКРАЇНСЬКИХ ІСТОРИКІВ
}

\author{
Шапорда В. А. \\ методист відділення морського та річкового транспорту \\ Державного вищого навчального закладу \\ «Миколаївський політехнічний коледж» \\ м. Миколаїв, Украӥна
}

Одними із важливих джерел для вивчення режиму А. І. Денікіна на Півдні України у 1918-1920 рр. є дисертаційні дослідження, тому важливо проаналізувати дисертації українських істориків 3 даної теми. У 1996 р. захистив кандидатську дисертацію з історіографії проблем російського білого руху в Україні, яка в 1998 р. вийшла окремою монографією, О. В. Козерод [1, 2]. Автор поставив собі завданням узагальнити й проаналізувати історію досліджень білого руху в Україні. На жаль, назва праці не зовсім відповідає предмету дослідження. У роботі спостерігається постійне перемикання уваги на історіографію проблеми боротьби з білим рухом, а подекуди й просто на громадянську війну. Аспект боротьби селян Півдня України 3 денікінським режимом розглядає у дисертації Ю.В. Котляр [3], а окремі епізоди перших сутичок військ Директорії УНР з російськими добровольцями в Одесі висвітлює у своїй дисертації В.А. Пархоменко [4]. У 2005 р. захистив кандидатську дисертацію по історії білого руху в Україні В.О. Крупина [5], а у 2006 р. - Я.В. Штанько [6]. В їх роботах розглядається процес зародження та функціонування білого руху, його ідеологічна платформа та внутрішня політика, поширення на теренах України, боротьба з радянською владою та стосунки 3 українськими національними урядами.

У 2009 р. була захищена дисертація доктора історичних наук С.В. Корновенка [7]. Фактологічний матеріал, теоретичні положення, висновки й узагальнення, які містяться у цій роботі, суттєво розширюють сучасні знання 3 історії країн Центральної та Південно- 
Східної Свропи початку XX ст., 3 історії революції та громадянської війни, білого руху Півдня Росії й аграрної політики урядів генерала А.І. Денікіна та генерала П.М. Врангеля у 1919 - 1920 рр. Продовженням даної тематики можна вважати докторську дисертацію О. А. Житкова [8], захищену у 2018 р. за спеціальністю 07.00 .06 історіографія, джерелознавство та спеціальні історичні дисципліни, окремий підрозділ якої присвячений аграрним проектам урядів А. Денікіна та П. Врангеля. Автор зробив аналіз сучасної української, російської, зарубіжної, в основному, емігрантської історіографії проблеми. На його думку в пострадянській історіографії плідно досліджувалися проекти аграрних перетворень білого руху. Було виявлено організаційні напрямки реалізації земельної політики урядів А. Денікіна і П. Врангеля в Україні. Зазначалося, що однією з причин військового краху Збройних сил Півдня Росії була недооцінка економічного потенціалу селянського господарства [8, с. 375].

У дисертації Ю. В. Білая [9] вперше в історичній науці здійснено реконструкцію подій у контексті діяльності державоохоронних структур білогвардійців як багатовимірного процесу. Визначена їх роль в контексті розвитку національно-визвольних змагань, охарактеризовано основні напрями діяльності й особливостей застосування спеціальних методів роботи. Зокрема, автором було визначено завдання державоохоронних структур білого руху на Півдні України. Одним із головних завдань державоохоронних структур мала стати нейтралізація більшовицького підпілля, яке на кінець 1918 р. - початок 1919 р. являло собою доволі розгалужену структуру на теренах південноукраїнського регіону та в Україні загалом. Протидія більшовицьким агентам та підпільникам носила характер неперервної та системної діяльності, що відрізнялася доволі високим рівнем скрупульозності, i, у той же час, - низькою професійністю з точки зору вибору методів боротьби. Значною мірою саме завдяки неправильно обраним методологічним засадам боротьби білогвардійці не змогли придушити більшовицьке підпілля й ліквідувати їх агентурну мережу.

Другою за значенням серед стратегічних ліній боротьби державоохоронних структур білого руху автор визначає українське підпілля. Військово-цивільне керівництво Збройних сил Півдня Росії розуміло, що їх соціальна база значно вужча на відміну від більшовиків та представників українського національного руху, а тому існувала необхідність якнайшвидше переорієнтувати більшість місцевого населення регіону з підтримки більшовиків та українського руху на свою сторону. Основною зброєю для цього визнано було роздрібнення українства, створення між різними угрупованнями атмосфери ворожості, несприйняття один одного, маргіналізація.

Третьою стратегічною лінією генеральної стратегії державоохоронних структур на Півдні України в контексті національно-визвольних 
змагань автор вважає протидію розгортанню повстанського руху, яка була повністю провалена. Так, анархістам вдалося сформувати не тільки доволі сильну військову структуру, а й дієву контррозвідку, яка доволі успішно боролася як 3 підрозділами Державної варти, так і зі спецслужбами білого руху [9, с. 15-16].

Дослідник встановив факт, що державоохоронні структури білого руху на теренах південноукраїнського регіону не являли собою настільки організовану та професійну систему, як це гіперболізовано представлено у більшості історичних доробків [10, с. 16].

Узагальнюючою роботою є дисертація М. В. Глібіщука [11], в якій автор розкрив основні напрями соціально-економічної політики уряду А. Денікіна в 1918-1920 рр. Дослідник розглянув процес формування денікінського урядового апарату, його структуру, склад. Проаналізував політику, яка реалізовувалася урядом А. Денікіна в соціальній та економічній сферах, основні труднощі, з якими стикнулося білогвардійське керівництво у цих сферах, та шляхи їх подолання. Дослідив агітаційно-пропагандистське забезпечення соціально-економічної політики денікінського режиму. Окреслив основні напрями білої пропаганди та ставлення до неї населення. Але потрібно зауважити, що в дисертації охоплені території, які впродовж вказаного періоду перебували під контролем білогвардійських військ. Це тогочасні області Донського, Кубанського і Терського козачих військ, вся територія Північного Кавказу, Воронезька, Курська, Орловська, Саратовська, Ставропольська, Тамбовська, Царицинська і Чорноморська губернії, велика частина території сучасної України, тобто робота написана, в основному, на матеріалах Півдня Росії.

Отже, можна констатувати, що хоча українські історики й зробили значний внесок у вивчення білого руху в Україні, але цей доробок недостатній для повного вивчення даного питання. Зокрема, потребують подальшого дослідження такі проблеми як: національна і культурна політика білого руху, стратегї̈ й практики виживання населення під час білогвардійської окупації, внутрішня та зовнішня політика білогвардійських урядів.

\section{Література:}

1. Козерод О.В., Бриман С.Ф. Деникинский режим и еврейское население Украины в 1919-1920 гг. Харьков: Курсор,1996. 56 с.

2. Козерод О.В. Историографические проблемы Белого движения в Украине. Харьков, 1998. 122 с.

3. Котляр Ю.В. Повстансько-партизанський рух українських селян у 1919 - на початку 1920 рр. (На матеріалах Півдня України): автореф. дис. ... канд. іст. наук : 07.00.01 / Одеський держ. ун-т ім. І. І. Мечникова. Одеса, 1997. 16 с. 
4. Пархоменко В. А. Українські національні військові формування на Півдні України у 1917 - на початку 1919 рр.: автореф. дис. ... канд. іст. наук : 07.00.01 / Донецький нац. ун-т. Донецьк, 2000. 19 с.

5. Крупина В. О. Білий рух в Україні (1917 -1920рр.) : автореф. дис. ... канд. іст. наук : 07.00.01 / Нац. акад. наук України, Ін-т історії України. Київ : Ін-т історії НАН України, 2005. 17 с.

6. Штанько Я.В. Білий рух півдня Росії і Українська Держава та УНР (1918-1920 рр.) : автореф. дис. ... канд. іст. наук : 07.00.02 / Чернівецький нац. ун-т ім. Ю. Федьковича. Чернівці, 2006. 20 с.

7. Корновенко С. В. Аграрна політика урядів А. Денікіна та П. Врангеля (1919-1920 рр.) : дис. ... д-ра іст. наук : 07.00.02 / Нац. акад. наук України, Ін-т історії України. Київ, 2009. 474 с.

8. Житков О. А. Аграрне питання та земельні реформи в Україні доби Визвольних змагань (1917-1921 рр.): історіографія: дис. ... д-ра іст. наук : 07.00.06 / Київ. нац. ун-т ім. Т. Шевченка. Київ, 2018. 551 с.

9. Білай Ю. В. Державоохоронні органи урядів А. Денікіна та П. Врангеля на Півдні України (1918-1920рр.): автореф. дис. ... канд. іст. наук : 07.00.01 / Запорізький нац. ун-т. Запоріжжя, 2019. 20 с.

10. Там само. С. 16.

11. Глібіщук М. В. Соціально-економічна політика уряду А. Денікіна (1918 - 1920 рр.): дис. ... канд. іст. наук : 07.00.02 / Чернівецький нац. ун-т ім. Ю. Федьковича. Чернівці, 2016. 229 с. 